\title{
Knowledge, attitude and practice (KAP) of sandwich under graduate students of Delta State University, Abraka, Nigeriaon condom use in the prevention of sexually transmitted infections (STls) and unwanted pregnancy.
}

\author{
Dr. CLARA AGBEDIA
}

\begin{abstract}
The study investigated the knowledge, attitude and practice (KAP) of sandwich under graduate students of Delta State University, Abraka, on condom use for the prevention of sexually transmitted infections (STls) and unwanted pregnancy. This is with a view of assessing the relevance of knowledge to attitude and practice. Three hypotheses were generated to guide the study. A self designed (KAP) questionnaire with 18 questions items were used to generate information. The sample was 610 students. Percentages and chi-square statistics were used to analyze the data. It was found that students had good knowledge of condom use towards the prevention of STls and unwanted pregnancy. There was also a relationship between knowledge and attitude. Males and females do not differ in their knowledge, attitude and practice of condom use. It was recommended that family and sexuality education be a part of the school curriculum, while the media should continuously be used to campaign for the use of condom in the prevention of STls and unwanted pregnancy.
\end{abstract}

Key words; knowledge, attitude, practice, condom, sexually transmitted infections (STls), unwanted pregnancy,

\section{Introduction}

Knowledge means understanding, awareness of a body of idea gained either by learning or experience. Knowledge makes for sensitivity and consciousness. Attitude is a way of behaving towards an issue(s) or circumstance. Hence Drouba (1952) stated that attitude is a mental disposition of an individual to act for or against a definite object and McDonald (1975) stated that "it is a pre-disposition to act in a positive or negative way towards persons or objects, ideas and events". Practice on the other hand is the real act in performance based on knowledge and attitude. Knowledge, attitude and practice (KAP) can be assumed as a chain of action, one influencing the other.

Condom use is generally accepted as a means of preventing sexually transmitted diseases such as gonorrhea, syphilis, HIV I AIDS and so on. It is also a means of preventing unwanted pregnancy; male condom is a sheath of polymer designed to fit the penis when worn while diaphragm is a cap that fits into the vagina. Condoms has been described as the most affordable barrier method available in most sub-Saharan African countries to prevent the spread of HIV / AIDS and sexually transmitted diseases

But the question is often asked: Does knowledge always influence attitude and practice? Would knowledge of condoms use and knowledge of the spread and prevention of STI influence males and females attitude, and sexual practice? Myer et al.( 2001) stated in their study that those who procured condoms on their own were more likely to use the condoms than those who received them as gift from health workers. The authors continued that individuals who had formal health education about condom use were also more likely to use their condoms than those who had no such education.

In another study, Lawoyin et al., (2000) reported Federal Office of Statistics in Nigeria that only 30\% of the adult population believed that there is protection against AIDS while $64 \%$ believed that there is none. The implication is that most men are not likely to use condoms since they do not believe it provides protection. Lawoyin et al.,(2000) reported in their own study that many men in their study were aware of the risks they have taken but still do not use condom which had the dual advantage of protecting against unwanted pregnancy and STIs. Similarly, ldowu et al.,(2003), reported in their study that adolescents are aware of condom use but do not use condom for the prevention of HIV/AIDS. In another similar study on knowledge and attitude, Moronkola and Akinterinwa (2003) study showed that despite the fact that male students have better knowledge of health consequences of tobacco smoking, female students with poorer knowledge level still record better attitude in disapproving smoking

The focus of this study is to examine the knowledge, attitude and practice of students towards condom use in the prevention and spread of STls and unwanted pregnancies.

This will help to improve the knowledge of condom use and consequently alter their attitude and practice toward safe sexual act. 


\section{Research Questions}

- Are sandwich undergraduate students of Delta State University Abraka (DELSU) knowledgeable about the use of condom in the prevention of sexually transmitted infections and unwanted pregnancy?

- Do these students have positive attitude and practice in the use of condom to prevent STIs and unwanted pregnancy?

- Do males and females sandwich undergraduate students differ in their knowledge, attitude and practice toward the prevention of sexually transmitted diseases and unwanted pregnancy?

\section{Research Hypotheses}

Ho 1: There is no significant relationship between knowledge, attitude and practice of condom use towards the prevention of STls and unwanted pregnancy among sandwich undergraduate students ofDeltaStateUniversity, Abraka.

Ho 2: Sandwich undergraduate students of Delta State University Abraka do not have positive attitude and practice in the use of condom towards the prevention of STls and unwanted pregnancy.

Ho 3: There is no significant relationship between males and females in knowledge, attitude and practice of condom use towards the prevention of STls and unwanted pregnancy

\section{Methodology}

The study adopted the ex post facto, descriptive survey design. The research population consisted of 3000 sandwich undergraduate students of Delta State University Abraka, 2006, (October/November contact). Both the quota and availability sampling methods were used to select the sample. The samples were selected equally across the Faculty of Education, Science, Arts and Social Science. 163 were allocated to each faculty. Using the availability sampling method, students on visit (male alternate a female was the mode of selection) to the faculty were given the questionnaire to complete and returned as soon possible. Six hundred and fifty (650) questionnaires were issued. Out of which 610 were correctly completed and returned, this translates to $93.85 \%$ returned rate. A self - designed KAP questionnaire was used to seek information. The first section of the questionnaires dealt with the bio-data of the subjects; the second section was constructed on the four scale likert pattern (i.e. $\mathrm{SA}=$ Strongly agreed, $\mathrm{A}=$ Agreed, $\mathrm{D}=$ Disagreed and $\mathrm{SD}=$ Strongly disagreed). The instrument was validated by experts in health education and test/measurement and found usable after little amendment. It was found reliable using test, retest, with a coefficient of .82. The statistical instrument was frequency count, percentages and Chi- square. The frequency count was reduced to manageable size by collapsing the cumulative frequency of the items in each of the variables.

\section{Findings}

The sandwich undergraduate students were selected on equal ratio males and females (50\% each). Their ages range between 22 years and 46 years with mean age of 29 years. Most of them were married (76\%; $37 \%$ males and 39\% females). There were mostly Christian (97\% 47\% males and $49 \%$ females). They were admitted with various qualifications (National Certificate in Education (NCE) 57\%, (males 29\%, females 28\%), National Diploma (ND); - $19 \%$, (males 10\%, females 9\%) and West African School Certificate (WASC) 22\%, (males 10\%, females 12\%).

Table 1: Distribution of respondents' knowledge of condom use in the prevention of STls and unwanted pregnancy

Total, $\mathrm{N}=610$

\begin{tabular}{|c|c|c|c|c|c|c|c|c|c|c|}
\hline & & & \multicolumn{4}{|c|}{ MALES: $\mathrm{N}=305$} & \multicolumn{4}{|c|}{ FEMALES: $\mathrm{N}=305$} \\
\hline $\begin{array}{l}\mathrm{S} / \\
\mathrm{N}\end{array}$ & ITEMS & & SA & A & $\mathrm{D}$ & SD & SA & A & $\mathrm{D}$ & SD \\
\hline \multirow[t]{2}{*}{1.} & \multirow{2}{*}{$\begin{array}{l}\text { STI (Sexual } \\
\text { Transmitted } \\
\text { infection) are serious } \\
\text { disease some of them } \\
\text { are capable of } \\
\text { lowering the body } \\
\text { immune system } \\
\text { causing death }\end{array}$} & $\mathrm{F}$ & 102 & 90 & 61 & 52 & 98 & 89 & 70 & 48 \\
\hline & & $\%$ & $\begin{array}{l}33.4 \\
4\end{array}$ & $\begin{array}{l}29.5 \\
0\end{array}$ & 20.0 & $\begin{array}{l}17.0 \\
4\end{array}$ & 32.13 & $\begin{array}{l}29.1 \\
8\end{array}$ & $\begin{array}{l}22.9 \\
5\end{array}$ & $\begin{array}{l}15.7 \\
3\end{array}$ \\
\hline \multirow[t]{2}{*}{2} & \multirow{2}{*}{$\begin{array}{l}\text { STI cannot be } \\
\text { detected on the face } \\
\text { especially at the latest }\end{array}$} & $\mathrm{F}$ & 118 & 112 & 52 & 23 & 122 & 108 & 48 & 27 \\
\hline & & $\%$ & $\begin{array}{l}38.6 \\
8\end{array}$ & $\begin{array}{l}36.7 \\
2\end{array}$ & $\begin{array}{l}17.0 \\
4\end{array}$ & 7.54 & 40.0 & $\begin{array}{l}35.4 \\
0\end{array}$ & $\begin{array}{l}15.7 \\
3\end{array}$ & 8.85 \\
\hline
\end{tabular}


Knowledge, attitude and practice (KAP) of sandwich under graduate students of Delta State

\begin{tabular}{|c|c|c|c|c|c|c|c|c|c|c|}
\hline & stage & & & & & & & & & \\
\hline \multirow[t]{2}{*}{3} & \multirow{2}{*}{$\begin{array}{l}\text { One of the major } \\
\text { sources of contacting } \\
\text { STI is through sexual } \\
\text { intercourse while } \\
\text { unwanted pregnancy is } \\
\text { a possibility. }\end{array}$} & $\mathrm{F}$ & 114 & 105 & 44 & 12.0 & 136 & 120 & 36 & 13 \\
\hline & & $\%$ & $\begin{array}{l}37.3 \\
7\end{array}$ & $\begin{array}{l}34.4 \\
2\end{array}$ & $\begin{array}{l}14.4 \\
2\end{array}$ & 3.93 & 44.59 & $\begin{array}{l}39.3 \\
4\end{array}$ & $\begin{array}{l}11.8 \\
0\end{array}$ & 4.26 \\
\hline \multirow[t]{2}{*}{4} & \multirow{2}{*}{$\begin{array}{l}\text { STI and unwanted } \\
\text { pregnancy can be } \\
\text { prevented with the sue } \\
\text { of condom }\end{array}$} & $\mathrm{F}$ & 160 & 125 & 20 & 0 & 140 & 125 & 40 & 0 \\
\hline & & $\%$ & $\begin{array}{l}52.4 \\
5\end{array}$ & $\begin{array}{l}40.9 \\
8\end{array}$ & 6.55 & 0 & 45.90 & $\begin{array}{l}40.9 \\
8\end{array}$ & $\begin{array}{l}13.1 \\
1\end{array}$ & 0 \\
\hline \multirow[t]{2}{*}{5} & \multirow{2}{*}{$\begin{array}{l}\text { Condom are found in } \\
\text { most shoes and are } \\
\text { very affordable }\end{array}$} & $\mathrm{F}$ & 125 & 104 & 53 & 50 & 130 & 100 & 48 & 27 \\
\hline & & $\%$ & $\begin{array}{l}40.9 \\
0\end{array}$ & $\begin{array}{l}34.0 \\
9 \\
\end{array}$ & $\begin{array}{l}17.3 \\
7 \\
\end{array}$ & $\begin{array}{l}16.3 \\
9\end{array}$ & 42.62 & 32.7 & $\begin{array}{l}15.7 \\
3\end{array}$ & 8.85 \\
\hline \multirow[t]{4}{*}{6} & \multirow{2}{*}{$\begin{array}{llr}\text { Condom } & \text { or } & \text { No } \\
\text { condom, } & \text { STI } & \text { or } \\
\text { pregnancy } & \text { can } & \text { still } \\
\text { occur } & & \\
\end{array}$} & $\mathrm{F}$ & 100 & 92 & 63 & 50 & 120 & 108 & 39 & 38 \\
\hline & & $\%$ & $\begin{array}{l}32.7 \\
8\end{array}$ & $\begin{array}{l}30.1 \\
6\end{array}$ & $\begin{array}{l}20.6 \\
5\end{array}$ & $\begin{array}{l}16.3 \\
9\end{array}$ & 39.34 & $\begin{array}{l}35.4 \\
0\end{array}$ & $\begin{array}{l}12.7 \\
8\end{array}$ & $\begin{array}{l}12.4 \\
5\end{array}$ \\
\hline & Total & & $\frac{749}{6}$ & 628 & 293 & 160 & 746 & 650 & 281 & 153 \\
\hline & Reduce to sample size & & $\begin{array}{l}125 . \\
0\end{array}$ & 105 & 49 & 27 & $\begin{array}{l}12 \\
5 \\
\end{array}$ & 108 & 47 & 26 \\
\hline
\end{tabular}

Table 1, explains the respondents' knowledge of condom use towards the prevention of STI and unwanted pregnancy. With 125 and 105, SA and A respectively for males and 125, 'SA' and 108 'A' for females, it goes to prove that sandwich undergraduate students of Delta State University were knowledgeable in the use of condom in the prevention of STIs and unwanted pregnancy.

Table 2 Distribution of respondents' attitude towards condom use in the prevention of STIs and unwanted pregnancy

\begin{tabular}{|c|c|c|c|c|c|c|c|c|c|c|}
\hline \multirow[b]{2}{*}{$\mathbf{S} / \mathbf{N}$} & \multirow[b]{2}{*}{ ITEMS } & & \multicolumn{4}{|c|}{ MALES:N=305 } & \multicolumn{4}{|c|}{ FEMALES: $\mathbf{N}=305$} \\
\hline & & & SA & $\mathbf{A}$ & D & SD & $\mathbf{S A}$ & $\mathbf{A}$ & D & SD \\
\hline \multirow[t]{2}{*}{1.} & \multirow{2}{*}{$\begin{array}{l}\text { Sexual intercourse is } \\
\text { recommended for married } \\
\text { persons only }\end{array}$} & $\mathrm{F}$ & 44 & 55 & 81 & 125 & 58 & 80 & 70 & 97 \\
\hline & & $\%$ & $\begin{array}{l}14.4 \\
2\end{array}$ & 18.03 & $\begin{array}{l}26.5 \\
5\end{array}$ & $\begin{array}{l}40.9 \\
8 \\
\end{array}$ & 19.01 & $\begin{array}{l}26.2 \\
2 \\
\end{array}$ & $\begin{array}{l}22.9 \\
5\end{array}$ & $\begin{array}{l}31.8 \\
0\end{array}$ \\
\hline \multirow[t]{2}{*}{2} & \multirow{2}{*}{$\begin{array}{l}\text { Causal sex can be } \\
\text { completely avoided }\end{array}$} & $\mathrm{F}$ & 22 & 60 & 102 & 121 & 40 & 80 & 98 & 87 \\
\hline & & $\%$ & 7.21 & 19.67 & 33.44 & $\begin{array}{l}39.6 \\
7\end{array}$ & 13.11 & $\begin{array}{l}22.2 \\
2\end{array}$ & $\begin{array}{l}32.1 \\
3\end{array}$ & $\begin{array}{l}28.5 \\
2\end{array}$ \\
\hline \multirow[t]{2}{*}{3} & \multirow{2}{*}{$\begin{array}{l}\text { The more the use of } \\
\text { condom, the less the } \\
\text { likelihood of being } \\
\text { infested with STIs }\end{array}$} & $\mathrm{F}$ & 142 & 99 & 38 & 26 & 138 & 111 & 32 & 24 \\
\hline & & $\%$ & $\begin{array}{l}46.5 \\
5\end{array}$ & 32.45 & $\begin{array}{l}12.4 \\
5\end{array}$ & 8.5 & 45.24 & $\begin{array}{l}36.3 \\
9\end{array}$ & $\begin{array}{l}10.4 \\
9\end{array}$ & 7.86 \\
\hline \multirow[t]{2}{*}{4} & \multirow{2}{*}{$\begin{array}{l}\text { With the use of condom, } \\
\text { premarital sex cannot be } \\
\text { completely condemned }\end{array}$} & $\mathrm{F}$ & 38 & 59 & 82 & 126 & 30 & 41 & 118 & 116 \\
\hline & & $\%$ & $\begin{array}{l}12.4 \\
5\end{array}$ & 19.34 & 26.88 & $\begin{array}{l}41.3 \\
1\end{array}$ & 9.83 & $\begin{array}{l}13.4 \\
4\end{array}$ & $\begin{array}{l}38.6 \\
5\end{array}$ & $\begin{array}{l}38.0 \\
3\end{array}$ \\
\hline \multirow[t]{2}{*}{5} & \multirow{2}{*}{$\begin{array}{l}\text { I always keep condom } \\
\text { within reach either in my } \\
\text { bag or at home in case of } \\
\text { "emergency" }\end{array}$} & $\mathrm{F}$ & 62 & 90 & 81 & 72 & 36 & 50 & 119 & 100 \\
\hline & & $\%$ & $\begin{array}{l}20.3 \\
2\end{array}$ & 29.50 & $\begin{array}{l}26.5 \\
5\end{array}$ & $\begin{array}{l}23.6 \\
0\end{array}$ & 11.80 & $\begin{array}{l}16.3 \\
9\end{array}$ & $\begin{array}{l}39.0 \\
1\end{array}$ & $\begin{array}{l}32.7 \\
8\end{array}$ \\
\hline \multirow[t]{4}{*}{6} & \multirow{2}{*}{$\begin{array}{l}\text { Multiple sex partners } \\
\text { create varieties and a } \\
\text { source of joy in sexual } \\
\text { intercourse. }\end{array}$} & $\mathrm{F}$ & 115 & 118 & 38 & 34 & 95 & 80 & 70 & 60 \\
\hline & & $\%$ & $\begin{array}{l}37.7 \\
0\end{array}$ & 38.68 & 12.45 & $\begin{array}{l}11.1 \\
4\end{array}$ & 31.14 & $\begin{array}{l}22.2 \\
2\end{array}$ & $\begin{array}{l}22.9 \\
5\end{array}$ & $\begin{array}{l}19.6 \\
7\end{array}$ \\
\hline & Cumulative frequency & & 423 & 481 & 422 & 504 & 397 & 442 & 507 & 484 \\
\hline & Frequency count & & 71 & $\begin{array}{l}80 . \\
00\end{array}$ & 70.0 & 84 & 66 & 74 & 84 & 81 \\
\hline
\end{tabular}

Table 2 depicts the attitude of males and females sandwich undergraduate students of Delta state university, Abraka on the use of condom for the prevention of STIs and unwanted pregnancy. With 71 and 80, SA and A respectively for males and 66, 'SA' and 74 ' $\mathrm{A}$ ' for females, the attitude on the use of condom for the prevention of STIs and unwanted pregnancy could be said to be negative. The distribution of the respondents on the options shows that there is no significant variability in the attitude between males and females. 
Table 3: Distribution of respondents practice on the use of condom in the prevention of STIs and unwanted pregnancy.

\begin{tabular}{|c|c|c|c|c|c|c|c|c|c|c|}
\hline & & & \multicolumn{4}{|c|}{ MALES:N=305 } & \multicolumn{4}{|c|}{ FEMALES: $\mathrm{N}=305$} \\
\hline $\mathbf{S} / \mathbf{N}$ & ITEMS & & SA & A & D & SD & SA & $\mathbf{A}$ & D & SD \\
\hline \multirow[t]{2}{*}{1.} & \multirow{2}{*}{$\begin{array}{l}\text { I always use condom in } \\
\text { all casual sex in my bid to } \\
\text { avoid STIs and unwanted } \\
\text { pregnancy }\end{array}$} & $\mathrm{F}$ & 30 & 50 & 100 & 125 & 60 & 65 & 87 & 93 \\
\hline & & $\%$ & 9.83 & 16.39 & $\begin{array}{l}32.7 \\
8\end{array}$ & $\begin{array}{l}40.5 \\
5\end{array}$ & 19.67 & $\begin{array}{l}21.3 \\
1\end{array}$ & $\begin{array}{l}28.5 \\
2\end{array}$ & $\begin{array}{l}30.4 \\
8\end{array}$ \\
\hline \multirow[t]{2}{*}{2} & \multirow{2}{*}{$\begin{array}{l}\text { I apply the condom } \\
\text { according to the } \\
\text { instruction of the } \\
\text { manufacturer or I do } \\
\text { encourage my partner to } \\
\text { follow instruction. }\end{array}$} & $\mathrm{F}$ & 55 & 75 & 80 & 95 & 50 & 55 & 100 & 117 \\
\hline & & $\%$ & $\begin{array}{l}18.0 \\
3\end{array}$ & 24.59 & 22.22 & $\begin{array}{l}31.1 \\
4\end{array}$ & 16.39 & $\begin{array}{l}18.0 \\
3\end{array}$ & $\begin{array}{l}32.7 \\
8\end{array}$ & $\begin{array}{l}38.3 \\
6\end{array}$ \\
\hline \multirow[t]{2}{*}{3} & \multirow{2}{*}{$\begin{array}{l}\text { When pressed, I do at } \\
\text { times forgo condom in } \\
\text { casual sex with risk of } \\
\text { STIs and unwanted } \\
\text { pregnancy }\end{array}$} & $\mathrm{F}$ & 70 & 66 & 100 & 75 & 42 & 60 & 70 & 132 \\
\hline & & $\%$ & $\begin{array}{l}22.9 \\
5\end{array}$ & 21.63 & $\begin{array}{l}32.7 \\
8\end{array}$ & $\begin{array}{l}24.5 \\
9\end{array}$ & 13.76 & $\begin{array}{l}19.6 \\
7\end{array}$ & $\begin{array}{l}22.9 \\
5\end{array}$ & $\begin{array}{l}43.2 \\
7\end{array}$ \\
\hline \multirow[t]{2}{*}{4} & \multirow{2}{*}{$\begin{array}{l}\text { My use of condom } \\
\text { depends on the } \\
\text { acceptance of my sexual } \\
\text { partner }\end{array}$} & $\mathrm{F}$ & 158 & 62 & 40 & 45 & 95 & 70 & 100 & 40 \\
\hline & & $\%$ & $\begin{array}{l}51.8 \\
0\end{array}$ & 20.32 & 13.11 & $\begin{array}{l}14.7 \\
5\end{array}$ & 31.14 & $\begin{array}{l}22.9 \\
5\end{array}$ & $\begin{array}{l}32.7 \\
8\end{array}$ & $\begin{array}{l}12.1 \\
1\end{array}$ \\
\hline \multirow[t]{2}{*}{5} & \multirow{2}{*}{$\begin{array}{l}\text { I best enjoy sexual } \\
\text { intercourse without a } \\
\text { condom. }\end{array}$} & $\mathrm{F}$ & 103 & 100 & 52 & 50 & 135 & 40 & 64 & 66 \\
\hline & & $\%$ & $\begin{array}{l}33.7 \\
7 \\
\end{array}$ & 32.78 & $\begin{array}{l}17.0 \\
4 \\
\end{array}$ & $\begin{array}{l}16.3 \\
9\end{array}$ & 44.26 & $\begin{array}{l}13.1 \\
1 \\
\end{array}$ & $\begin{array}{l}20.9 \\
8 \\
\end{array}$ & $\begin{array}{l}21.6 \\
3 \\
\end{array}$ \\
\hline \multirow[t]{4}{*}{6} & \multirow{2}{*}{$\begin{array}{l}\text { I have had sexual } \\
\text { intercourse within the last } \\
\text { one year without a } \\
\text { condom }\end{array}$} & $\mathrm{F}$ & 177 & 60 & 38 & 30 & 150 & 42 & 60 & 50 \\
\hline & & $\%$ & $\begin{array}{l}58.0 \\
3\end{array}$ & 19.67 & 12.45 & 9.83 & 49.10 & $\begin{array}{l}13.7 \\
6\end{array}$ & $\begin{array}{l}19.6 \\
7\end{array}$ & $\begin{array}{l}16.3 \\
9\end{array}$ \\
\hline & Cumulative frequency & & 593 & 413 & 410 & 422 & 532 & 332 & 481 & 498 \\
\hline & Frequency count & & 98 & $\begin{array}{l}69 . \\
0 \\
\end{array}$ & 68 & 70.0 & 88 & 55 & 80 & 82 \\
\hline
\end{tabular}

Table 3, shows the analysis of the practice of condom use among sandwich undergraduate students of Delta State University, Abraka. With 98 and 69, SA and A respectively for males and 88, 'SA' and 55 'A' for females, only 310 students actively support the use of condom in the prevention of STIs and unwanted pregnancy. From the even distribution in scores for both males and females, it can be concluded that these students are neither positive nor negative in their actual use of condom. Thus, do not use condom in the prevention of STIs and unwanted pregnancy.

\section{Hypothesis I}

Thereis no significant relationship between knowledge and attitude/practice of condom use towards the prevention of STls and avoidance of unwanted pregnancy among sandwich undergraduate students of Delta State University, Abraka

Table 4: Chi-square statistic of the relationship between knowledge, and attitude/practice of condom use among sandwich undergraduates students of Delta State. University, Abraka, on prevention of STI and $\mathrm{N}=60$ avoidance of unwanted pregnancy.

\begin{tabular}{|l|l|l|c|l|l|}
\hline & & SA & A & D & SD \\
\hline Knowledge & Ob. & 249 & 213 & 96 & 52 \\
\hline & Exp. & 205 & 176.6 & 124 & 104.5 \\
\hline $\begin{array}{l}\text { Attitude/ } \\
\text { practice }\end{array}$ & Ob. & 161 & 140 & 15 & 157 \\
\hline & Exp & 205 & 176.5 & 124 & 104.5 \\
\hline
\end{tabular}

Cal. $\quad \begin{array}{rr}\mathrm{X}^{2}= & 9.40 \\ = & 99\end{array} \quad+7.50+6.32+26.37+9.44+7.50+26.37$




$\begin{array}{lll}\text { df } & = & 3 \\ \text { Alpha } & = & 0.05 \\ \text { Table value } & = & 7.81 \\ \text { Decision Rejected } & \end{array}$

Table 4 shows that the calculated $X^{2}$ value of knowledge was 99 at df of and alpha of 0.05 while the table value was 7.81. Thus the hypothesis was rejected. There was therefore, significant relationship between knowledge and attitude and practice of condom use in the prevention of STls and unwanted pregnancy

\section{Hypothesis 2}

Sandwich undergraduate students of Delta State University, Abraka do not have significant positive attitude/practice in the use of condom towards the prevention of STls and unwanted pregnancy.

Table 5:Chi-square statistic of Sandwich undergraduate students of Delta State University, on their $\mathbf{N}=610$ positive attitude / practice of condom use in the prevention of STIs and unwanted pregnancy

\begin{tabular}{|l|l|l|l|l|l|}
\hline Variables & & SA & A & D & SD \\
\hline \multirow{3}{*}{ Knowledge } & Ob. & 162 & 140.0 & 151.0 & 157.0 \\
\cline { 2 - 6 } & Exp. & 152.85 & 152.85 & 152.85 & 152.85 \\
\hline
\end{tabular}

Cal. $X^{2}=0.54+0.99+0.13+0.01$

$$
\begin{aligned}
& 1.67 \\
& \text { df } \\
& \text { alpha }=0.05 \\
& \text { Table value }=\quad 7.81 \\
& \text { Decision Accepted }
\end{aligned}
$$

Table 5: shows that the calculated $X^{2}$ value of attitude and practice as of 1.67 at df 3 and alpha 0.05 . The critical value was 7.81. Thus, the hypothesis was accepted that, sandwich undergraduate student of Delta State University, Abraka have no significant positive attitude on the use of condom in the prevention of STIs and unwanted pregnancy.

\section{Hypothesis 3:}

There is no significant relationship between males and females in their knowledge, attitude and practice of condom use towards the prevention of STls and unwanted pregnancy.

Table 6: Chi-square statistic on the Relationship between males and females sandwichndergraduate students of Delta State University, Abraka on condom use as prevention of STIs and unwanted

$\mathrm{M}=305$ pregnancy

$\mathrm{F}=305 \quad=610$

\begin{tabular}{|l|l|l|l|l|l|}
\hline Variables & & SA & A & D & SD \\
\hline \multirow{4}{*}{ Males } & Ob. & 94 & 86 & 64 & 61 \\
\cline { 2 - 6 } Females & Exp. & 92.38 & 81.95 & 66.55 & 61.09 \\
& Ob. & 93.0 & 79.0 & 71.0 & 62.0 \\
\cline { 2 - 6 } & Exp & 92.61 & 83.04 & 67.44 & 61.90 \\
\hline
\end{tabular}

Cal. $\quad X^{2}=0.004+0.20+0.189+0.19+0.003+0.19+0.18+0.019$ df $\quad=\quad 3$

Alpha $\quad=\quad 0.05$

Table value $\quad=\quad 7.81$

Decision Accepted

Table 6 explains the calculated $\mathrm{X}^{2}$ value of males against females was 0.80 at $\mathrm{df} 3$ at 0.05 alpha. The critical value was at 7.81 . The hypothesis is therefore accepted. Thus there is no significant relationship between males and females in their knowledge, attitude and practice of condom use in their prevention of STIs and unwanted 
pregnancy.

\section{Discussions}

The rejection of Hypothesis 1 shows that students were knowledgeable on the use of condom in the prevention of STls and unwanted pregnancy. The acceptance of Hypothesis $\mathbf{2}$ shows that students of Delta state university, Abraka had poor attitude and practice towards condom use in the prevention of STIs and of unwanted pregnancy. This finding correlates and supports the findings of Lawoyin et al (2000) who stated that many men were aware of the risks they have taken but still do not use condom which had duel advantage of protecting against unwanted pregnancy and STIs. Also Idowu et al (2003) reported in their study that adolescents were aware of condom use but do not use condom for the prevention of HIV / AIDs. The acceptance of Hypothesis 3 shows that males and females do not differ in their knowledge, attitude and practice of condom use. Although there are no direct study between males and females on the use of condom but similar study on health knowledge and behavior reported various variations. Moronkola and Akintarinwa (2003) reported that despite the fact that males' students have better knowledge of the health consequences of tobacco smoking, females' students with poor knowledge still record better attitude in disapproving smoking. However the findings of this study were at variance with that of Moronkola and Akinterinwa (2003).

\section{Conclusion}

This study has shown that knowledge do not influence attitude and practice on condom use in the prevention and unwanted pregnancy. Males and females do not differ in their knowledge, attitude and practice of condom use. The implication for this study is that the use of condom in the prevention and unwanted pregnancy should remain a priority area of interest in health education programme, public health campaign, among health educators, health workers and the government. The print and electronic media should continually use jingo and public enlightenment programmeto promote condom-use. Communicable diseases and family planning should be introduced into adult literacy classes and general studies in higher education. In addition, curriculum of primary and secondary schools should be enriched with reproductive health issues such as family health and sexuality to provide the information at earlier age in life.

\section{Reference}

[1] Drouba, S. (1952). Elements of park and recreation administration, Burges Publication Co. pp. 84-85.

[2] Idowu, B; Adeogun, J. Dansu, A; (2003) Condon use among Adolescents: an antidote to prevention of AIDS in Oshodi/Isolo Local Education District. School Health Journal 15; 1 \& 2; 75 -81.

[3] Lawoyin TO., Walker M. Osinowo H. (2000) Socio-demographic factors, Condom use and sexually transmitted infection among married men in Ibadan, Nigeria African Journal of Reproductive Health 4, 2; 85 - 92.

[4] McDonald, B.F. (1975). Physical Education for the physical, Ist Ed.Periodical Hull Inc.p.45.

[5] Moronkola O A. and Imafidon I. (1998). Attitude towards Aids and Sexual behavior of university students: Implication for Health Education, Nigerian School Health Journal, 10, 1 \& 2,38-44.

[6] Moronkola, O. A and Akinterinua, TO. (2003), Gender differences in knowledge and attitude towards tobacco smoking among university of Ibadan students. West African Journal of Physical and Health Education7; 212-218.

[7] Myer L., Mathews C, \& Little F. (2001). Tracing condom fates: design and pilot results of a study investigating the use and wastage of condoms. African Journal of Reproductive Health 5, 1, 66-74.

[8] Ogundele, B.O. (2004). The level of awareness of students of Federal College of Education (special) Oyo about spread and prev ention of AIDS. Nigerian School Health Journal, 16, 1 \& 2, 107-116.

[9] Oladepo, O. and Brieger, W.R. (2000). Sexual Attitudes and behaviour of male secondary school students in rural and urban areas of Oyo State, Nigeria. African Journal of Reproductive Health. 4,2, 2 1-34 